\title{
Editorial
}

\section{Welcome to Seminars in Thrombosis and Hemostasis 2020-New (2018) Impact Factor and Most Highly Cited Papers}

\author{
Emmanuel J. Favaloro, PhD, FFSc (RCPA) ${ }^{1}$ \\ ${ }^{1}$ Department of Haematology, Centres for Thrombosis and \\ Haemostasis, Institute of Clinical Pathology and Medical Research \\ (ICPMR), Westmead Hospital, Westmead, New South Wales, \\ Australia
}

\section{Semin Thromb Hemost 2020;46:1-5.}

Welcome to the start of another year with Seminars in Thrombosis and Hemostasis (STH), this being my 12th year anniversary as Editor-in-Chief. As always, I wish to again sincerely thank all contributors to STH over the years, as well as guest editors for past issues, and of course the current and past editorial team. There has been no major overhaul of the editorial team at the time of writing, although some adjustments have and will continue to occur over coming years.

I also take this opportunity to once again thank the journal production team at Thieme Medical Publishers for their high production standards and for facilitating both the print and online issues of the journal. In particular, I would like to thank Ananya Das, the production editor for $S T H$, and her production team, as well as Wakiko Ishii, an assistant acquisitions editor, for their ongoing support.

This now annual editorial also represents the time that we reflect on our journal's Impact Factor, which for 2018 was 3.401, which represents a small increase from our 2017 Impact Factor of 3.345. I also assessed the trends for self-citations, and this reflects positively for recent data ( - Fig. 1). Finally, I also

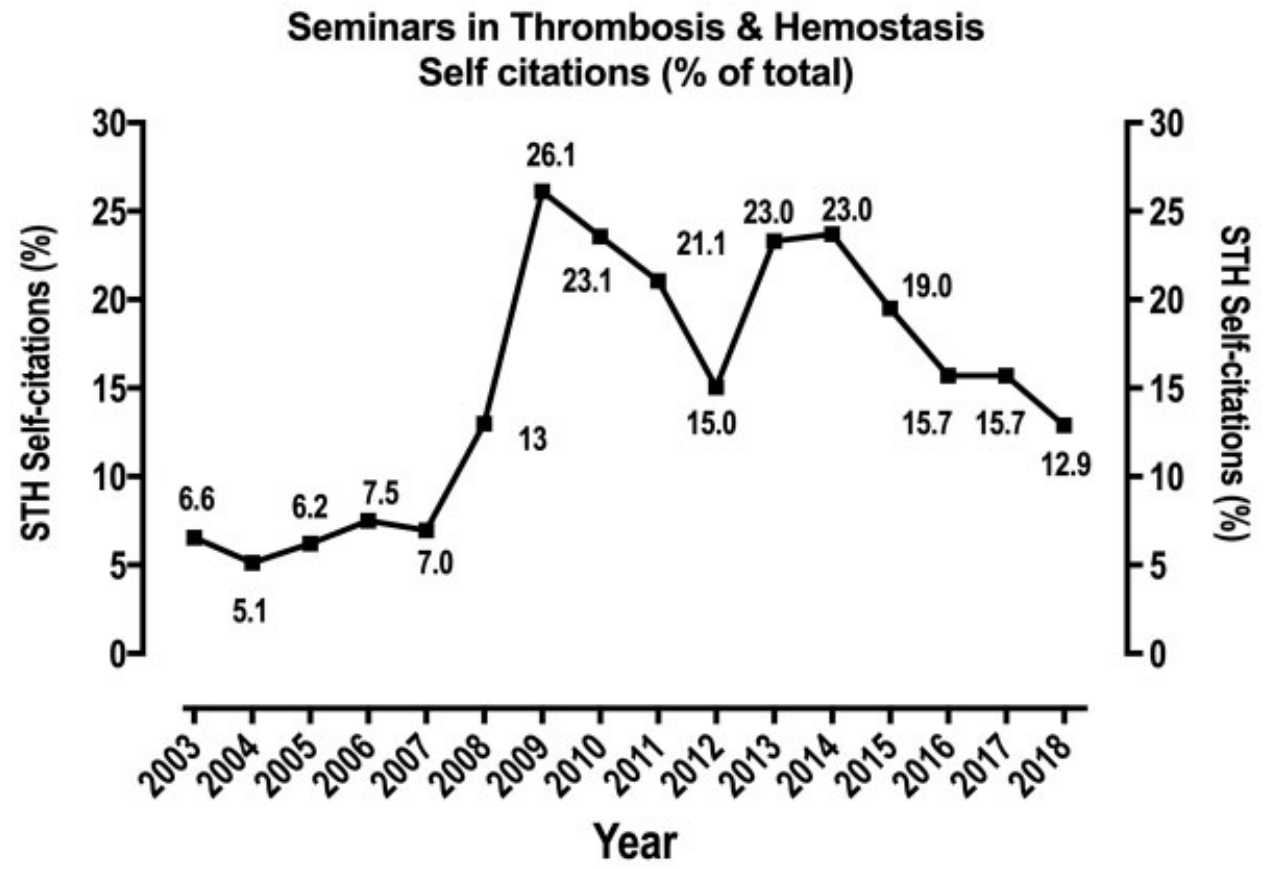

Fig. 1 Percentage of self-citations for Seminars in Thrombosis and Hemostasis in recent years-aiming for less.

Address for correspondence Emmanuel J. Favaloro, PhD, FFSc (RCPA), Department of

Haematology, Centres for

Thrombosis and Haemostasis,

Institute of Clinical Pathology and Medical Research (ICPMR),

Westmead Hospital, Westmead, New South Wales 2145, Australia (e-mail: emmanuel.favaloro@ health.nsw.gov.au).
Issue Theme Perioperative Hemostasis; Guest Editors: Beverley J. Hunt, FRCP, FRCPath, $M D$, and Jerrold $H$. Levy, MD, FAHA, FCCM.
Copyright (c) 2020 by Thieme Medical Publishers, Inc., 333 Seventh Avenue, New York, NY 10001, USA. Tel: +1(212) 584-4662.
DOI https://doi.org/ 10.1055/s-0039-1701014. ISSN 0094-6176. 
assessed how STH compared with several "comparable" journals focused on bleeding and/or thrombosis, and of 10 such journals, about half showed an increase, while the remainder showed a reduction or no change, in Impact Factor. In any case, the Impact Factor is only one of several markers of journal "quality" that we should consider, and the limitations of any individual marker (including the Impact Factor) as a "quality" indicator have previously been discussed. ${ }^{1,2}$

As I also do annually now, the highest cited (2016/2017published) contributions ${ }^{3-38}$ from this journal are also listed in - Table 1 for the potential interest of the readership and contributing authors. These contributions identify those publications most contributing to the 2018 Impact Factor, and each were cited six or more times in the literature in 2018. For those interested, the current listing can be compared with those of the most recently published top downloaded article listings from STH, the basis of the Eberhard F. Mammen "Most Popular" awards. ${ }^{39-42}$ Accordingly, I would like to thank all the contributors, guest editors, and the editorial team for bringing us the content that makes STH.

Table 1 Top 2018-cited papers, as published in 2016/2017
One paper I will highlight in particular is from the co-authorship team of Gremmel, Frelinger, and Michelson. ${ }^{3}$ This paper was the most highly cited from the listing in - Table 1, having been cited 17 times in 2018. Although this in itself reflects on the importance of the work, in this case the importance to other citing authors, what is also notable is that this paper was also one of the most popular from the perspective of downloads, leading the list from the "general category" in 2018. ${ }^{41}$ Although we do not normally canvass commentary from authors of the highest cited papers, leaving that honor to winners of the Most Popular and Young Investigator awards, ${ }^{39-42}$ we will make an exception in this case. When the news was broken to the authorship team, Dr. Gremmel responded on their behalf by stating: "I am very delighted that our review on platelet physiology was the most highly cited paper from Seminars in Thrombosis and Hemostasis in 2018. I would like to thank my co-authors Alan D. Michelson and Andrew L. Frelinger for their support and for our fruitful collaboration over the years. It is a great pleasure to work with two of the most distinguished researchers in the field.

\footnotetext{
1. Gremmel T, Frelinger AL III, Michelson AD. Platelet physiology. Semin Thromb Hemost 2016;42(3):191-204

2. Berntorp E, Andersson NG. Prophylaxis for hemophilia in the era of extended half-life factor VIII/factor IX products. Semin Thromb Hemost 2016;42(5):518-525

3. Douxfils J, Gosselin RC. Laboratory assessment of direct oral anticoagulants. Semin Thromb Hemost 2017;43(3):277-290

4. Curnow J, Pasalic L, Favaloro EJ. Treatment of von Willebrand disease. Semin Thromb Hemost 2016;42(2):133-146

5. Flevaris $P$, Vaughan D. The role of plasminogen activator inhibitor type-1 in fibrosis. Semin Thromb Hemost 2017;43 (2):169-177

6. Schreiber K, Breen K, Cohen H, et al. HYdroxychloroquine to Improve Pregnancy Outcome in Women with AnTIphospholipid Antibodies (HYPATIA) protocol: a multinational randomized controlled trial of hydroxychloroquine versus placebo in addition to standard treatment in pregnant women with antiphospholipid syndrome or antibodies. Semin Thromb Hemost 2017;43 (6):562-571
}

7. Naudin C, Burillo E, Blankenberg S, Butler L, Renné T. Factor XII contact activation. Semin Thromb Hemost 2017;43 (8):814-826

8. Ramström S, Södergren AL, Tynngård N, Lindahl TL. Platelet function determined by flow cytometry: new perspectives? Semin Thromb Hemost 2016;42(3):268-281

9. Montoro-García S, Schindewolf M, Stanford S, Larsen OH, Thiele T. The role of platelets in venous thromboembolism. Semin Thromb Hemost 2016;42(3):242-251

10. Schroeder V, Kohler HP. Factor XIII: structure and function. Semin Thromb Hemost 2016;42(4):422-428

11. Litvinov RI, Weisel JW. What is the biological and clinical relevance of fibrin? Semin Thromb Hemost 2016;42(4):333-343

12. Neerman-Arbez M, de Moerloose P, Casini A. Laboratory and genetic investigation of mutations accounting for congenital fibrinogen disorders. Semin Thromb Hemost 2016;42(4):356-365

13. Casini A, de Moerloose P, Neerman-Arbez M. Clinical features and management of congenital fibrinogen deficiencies. Semin Thromb Hemost 2016;42(4):366-374

14. Gall LS, Brohi K, Davenport RA. Diagnosis and treatment of hyperfibrinolysis in trauma (a European perspective). Semin Thromb Hemost 2017;43(2):224-234

15. Jiménez-Alcázar M, Kim N, Fuchs TA. Circulating extracellular DNA: cause or consequence of thrombosis? Semin Thromb Hemost 2017;43(6):553-561

16. Gando S, Hayakawa M. Pathophysiology of trauma-induced coagulopathy and management of critical bleeding requiring massive transfusion. Semin Thromb Hemost 2016;42(2):155-165

17. Gresele P, Bury L, Falcinelli E. Inherited platelet function disorders: algorithms for phenotypic and genetic investigation. Semin Thromb Hemost 2016;42(3):292-305

18. Undas A. How to assess fibrinogen levels and fibrin clot properties in clinical practice? Semin Thromb Hemost 2016;42 (4):381-388 
19. Mannucci PM, Mancuso ME, Santagostino E, Franchini M. Innovative pharmacological therapies for the hemophilias not based on deficient factor replacement. Semin Thromb Hemost 2016;42(5):526-532

20. Reynen E, James P. Von Willebrand disease and pregnancy: a review of evidence and expert opinion. Semin Thromb Hemost 2016;42(7):717-723

21. Hess S, Frary EC, Gerke O, Madsen PH. State-of-the-art imaging in pulmonary embolism: ventilation/perfusion single-photon emission computed tomography versus computed tomography angiography - controversies, results, and recommendations from a systematic review. Semin Thromb Hemost 2016;42(8):833-845

24. Walsh M, Shreve J, Thomas S, et al. Fibrinolysis in trauma: "myth," "reality," or "something in between". Semin Thromb Hemost 2017;43(2):200-212

23. Kitchen S, Tiefenbacher S, Gosselin R. Factor activity assays for monitoring extended half-life FVIII and factor IX replacement therapies. Semin Thromb Hemost 2017;43(3):331-337

24. Lippi G, Franchini M, Favaloro EJ. Diagnostics of inherited bleeding disorders of secondary hemostasis: an easy guide for routine clinical laboratories. Semin Thromb Hemost 2016;42(5):471-477

25. Lisman T, Ariëns RA. Alterations in fibrin structure in patients with liver diseases. Semin Thromb Hemost 2016;42 (4):389-396

26. Muszbek L, Katona É. Diagnosis and management of congenital and acquired FXIII deficiencies. Semin Thromb Hemost 2016;42(4):429-439

27. Prandoni P, Bernardi E, Valle FD, et al. Extensive computed tomography versus limited screening for detection of occult cancer in unprovoked venous thromboembolism: a multicenter, controlled, randomized clinical trial. Semin Thromb Hemost 2016;42(8):884-890

28. Crous-Bou M, Harrington LB, Kabrhel C. Environmental and genetic risk factors associated with venous thromboembolism. Semin Thromb Hemost 2016;42(8):808-820

29. Favaloro EJ, Pasalic L, Curnow J. Monitoring therapy during treatment of von Willebrand disease. Semin Thromb Hemost 2017;43(3):338-354

30. Lordkipanidzé M. Platelet function tests. Semin Thromb Hemost 2016;42(3):258-267

31. Castaman G, Eckhardt C, van Velzen A, Linari S, Fijnvandraat K. Emerging issues in diagnosis, biology, and inhibitor risk in mild hemophilia A. Semin Thromb Hemost 2016;42(5):507-512

32. Silvis SM, Middeldorp S, Zuurbier SM, Cannegieter SC, Coutinho JM. Risk factors for cerebral venous thrombosis. Semin Thromb Hemost 2016;42(6):622-631

33. Just S. Laboratory testing for von Willebrand disease: the past, present, and future state of play for von Willebrand factor assays that measure platelet binding activity, with or without ristocetin. Semin Thromb Hemost 2017;43(1):75-91

34. Foley JH. Plasmin(ogen) at the nexus of fibrinolysis, inflammation, and complement. Semin Thromb Hemost 2017;43 (2):135-142

35. Castellone DD, Adcock DM. Factor VIII activity and inhibitor assays in the diagnosis and treatment of hemophilia A. Semin Thromb Hemost 2017;43(3):320-330

36. Angelini D, Khorana AA. Risk assessment scores for cancer-associated venous thromboembolic disease. Semin Thromb Hemost 2017;43(5):469-478

${ }^{a}$ Cited six or more times in 2018; thus, contributing most to the STH 2018 Impact Factor.

Moreover, I am grateful that the journal made our article freely available following the 2018 Eberhard F. Mammen Award, which has certainly fostered its further distribution. Finally, I would like to thank all colleagues for their continued interest in our review article. Since Seminars in Thrombosis and Hemostasis publishes so many excellent papers, it is indeed a great honour that our article was the most highly cited within the last year."

Several issues of the journal are also worthy of highlighting as most contributing to the 2018 Impact Factor. The five most highly contributing issues, ${ }^{43-47}$ both in terms of total and average Impact Factor contributions, were as follows:

1. The Role of Fibrinogen and Factor XIII in Hemostasis, and the Identification and Treatment of Associated Disorders. Guest Editors: Ton Lisman, Philippe de Moerloose.
2. Platelet Function in Thrombosis and Hemostasis. Guest Editor: Anne-Mette Hvas.

3. Controversies in Inherited Bleeding Disorders. Guest Editors: Antonio Coppola, Massimo Franchini, and Annarita Tagliaferri.

4. Fibrinolysis: Biochemistry, Clinical Aspects, and Therapeutic Potential. Guest Editors: Hau Kwaan, Ton Lisman, and Robert Medcalf.

5. Laboratory Assessment of Hemostatic and Anticoagulant Therapy. Guest Editors: Dorothy M. Adcock, Robert C. Gosselin.

Finally, a short note to confirm that we, as always, will continue to develop plans for the future content of this journal, and we are confident that STH will be able to 
Table 2 Current planned topics for future issues of Seminars in Thrombosis and Hemostasis

\begin{tabular}{|l|}
\hline - Editorial compilations (continuing series) \\
\hline $\begin{array}{l}\text { - Recent advances in thrombosis and hemostasis } \\
\text { (continuing series) }\end{array}$ \\
\hline - Nanotechnology in thrombosis and hemostasis \\
\hline - Perioperative thrombosis and hemostasis \\
\hline - Innovations in thrombosis and hemostasis, part II: \\
focus on tests and assays \\
\hline - Acquired platelet dysfunction-laboratory and clinical \\
implications \\
\hline - Hemostasis and thrombosis in patients with liver disease \\
\hline - The complexity of trauma-induced coagulopathy \\
\hline - Hemostatic and nonhemostatic effects of heparan \\
sulfate proteoglycans \\
\hline
\end{tabular}

continue to bring its readers the high-quality journal that is expected of us. Currently confirmed topics for issues that we plan to publish over the next 12 or so months are listed in -Table 2. At the same time, we recognize the need to retain some flexibility in our plans, and to potentially add additional material of current interest and controversy as the need arises. We look forward to another interesting year of reading in 2020 .

\section{Conflicts of Interest \\ None declared.}

\section{References}

1 Favaloro EJ. The Journal Impact Factor: don't expect its demise any time soon. Clin Chem Lab Med 2009;47(11):1319-1324

2 Favaloro EJ. Measuring the quality of journals and journal articles: the impact factor tells but a portion of the story. Semin Thromb Hemost 2008;34(01):7-25

3 Gremmel T, Frelinger AL III, Michelson AD. Platelet physiology. Semin Thromb Hemost 2016;42(03):191-204

4 Berntorp E, Andersson NG. Prophylaxis for hemophilia in the era of extended half-life factor VIII/factor IX products. Semin Thromb Hemost 2016;42(05):518-525

5 Douxfils J, Gosselin RC. Laboratory assessment of direct oral anticoagulants. Semin Thromb Hemost 2017;43(03):277-290

6 Curnow J, Pasalic L, Favaloro EJ. Treatment of von Willebrand disease. Semin Thromb Hemost 2016;42(02):133-146

7 Flevaris P, Vaughan D. The role of plasminogen activator inhibitor type-1 in fibrosis. Semin Thromb Hemost 2017;43(02):169-177

8 Schreiber K, Breen K, Cohen H, et al. HYdroxychloroquine to Improve Pregnancy Outcome in Women with AnTIphospholipid Antibodies (HYPATIA) protocol: a multinational randomized controlled trial of hydroxychloroquine versus placebo in addition to standard treatment in pregnant women with antiphospholipid syndrome or antibodies. Semin Thromb Hemost 2017; 43(06):562-571

9 Naudin C, Burillo E, Blankenberg S, Butler L, Renné T. Factor XII contact activation. Semin Thromb Hemost 2017;43(08):814-826

10 Ramström S, Södergren AL, Tynngård N, Lindahl TL. Platelet function determined by flow cytometry: new perspectives? Semin Thromb Hemost 2016;42(03):268-281
11 Montoro-García S, Schindewolf M, Stanford S, Larsen OH, Thiele T. The role of platelets in venous thromboembolism. Semin Thromb Hemost 2016;42(03):242-251

12 Schroeder V, Kohler HP. Factor XIII: structure and function. Semin Thromb Hemost 2016;42(04):422-428

13 Litvinov RI, Weisel JW. What is the biological and clinical relevance of fibrin? Semin Thromb Hemost 2016;42(04):333-343

14 Neerman-Arbez M, de Moerloose P, Casini A. Laboratory and genetic investigation of mutations accounting for congenital fibrinogen disorders. Semin Thromb Hemost 2016;42(04):356-365

15 Casini A, de Moerloose P, Neerman-Arbez M. Clinical features and management of congenital fibrinogen deficiencies. Semin Thromb Hemost 2016;42(04):366-374

16 Gall LS, Brohi K, Davenport RA. Diagnosis and treatment of hyperfibrinolysis in trauma (a European perspective). Semin Thromb Hemost 2017;43(02):224-234

17 Jiménez-Alcázar M, Kim N, Fuchs TA. Circulating extracellular DNA: cause or consequence of thrombosis? Semin Thromb Hemost 2017;43(06):553-561

18 Gando S, Hayakawa M. Pathophysiology of trauma-induced coagulopathy and management of critical bleeding requiring massive transfusion. Semin Thromb Hemost 2016;42(02):155-165

19 Gresele P, Bury L, Falcinelli E. Inherited platelet function disorders: algorithms for phenotypic and genetic investigation. Semin Thromb Hemost 2016;42(03):292-305

20 Undas A. How to assess fibrinogen levels and fibrin clot properties in clinical practice? Semin Thromb Hemost 2016;42(04):381-388

21 Mannucci PM, Mancuso ME, Santagostino E, Franchini M. Innovative pharmacological therapies for the hemophilias not based on deficient factor replacement. Semin Thromb Hemost 2016;42 (05):526-532

22 Reynen E, James P. Von Willebrand disease and pregnancy: a review of evidence and expert opinion. Semin Thromb Hemost 2016;42(07):717-723

23 Hess S, Frary EC, Gerke O, Madsen PH. State-of-the-art imaging in pulmonary embolism: ventilation/perfusion single-photon emission computed tomography versus computed tomography angiography - controversies, results, and recommendations from a systematic review. Semin Thromb Hemost 2016;42(08):833-845

24 Walsh M, Shreve J, Thomas S, et al. Fibrinolysis in trauma: "myth," "reality," or "something in between". Semin Thromb Hemost 2017;43(02):200-212

25 Kitchen S, Tiefenbacher S, Gosselin R. Factor activity assays for monitoring extended half-life FVIII and factor IX replacement therapies. Semin Thromb Hemost 2017;43(03):331-337

26 Lippi G, Franchini M, Favaloro EJ. Diagnostics of inherited bleeding disorders of secondary hemostasis: an easy guide for routine clinical laboratories. Semin Thromb Hemost 2016;42(05):471-477

27 Lisman T, Ariëns RA. Alterations in fibrin structure in patients with liver diseases. Semin Thromb Hemost 2016;42(04):389-396

28 Muszbek L, Katona É. Diagnosis and management of congenital and acquired FXIII deficiencies. Semin Thromb Hemost 2016;42 (04):429-439

29 Prandoni P, Bernardi E, Valle FD, et al. Extensive computed tomography versus limited screening for detection of occult cancer in unprovoked venous thromboembolism: a multicenter, controlled, randomized clinical trial. Semin Thromb Hemost 2016;42(08):884-890

30 Crous-Bou M, Harrington LB, Kabrhel C. Environmental and genetic risk factors associated with venous thromboembolism. Semin Thromb Hemost 2016;42(08):808-820

31 Favaloro EJ, Pasalic L, Curnow J. Monitoring therapy during treatment of von Willebrand disease. Semin Thromb Hemost 2017;43(03):338-354

32 Lordkipanidzé M. Platelet function tests. Semin Thromb Hemost 2016;42(03):258-267 
33 Castaman G, Eckhardt C, van Velzen A, Linari S, Fijnvandraat K. Emerging issues in diagnosis, biology, and inhibitor risk in mild hemophilia A. Semin Thromb Hemost 2016;42(05):507-512

34 Silvis SM, Middeldorp S, Zuurbier SM, Cannegieter SC, Coutinho JM. Risk factors for cerebral venous thrombosis. Semin Thromb Hemost 2016;42(06):622-631

35 Just S. Laboratory testing for von Willebrand disease: the past, present, and future state of play for von Willebrand factor assays that measure platelet binding activity, with or without ristocetin. Semin Thromb Hemost 2017;43(01):75-91

36 Foley JH. Plasmin(ogen) at the nexus of fibrinolysis, inflammation, and complement. Semin Thromb Hemost 2017;43(02):135-142

37 Castellone DD, Adcock DM. Factor VIII activity and inhibitor assays in the diagnosis and treatment of hemophilia A. Semin Thromb Hemost 2017;43(03):320-330

38 Angelini D, Khorana AA. Risk assessment scores for cancerassociated venous thromboembolic disease. Semin Thromb Hemost 2017;43(05):469-478

39 Favaloro EJ. 2017 Eberhard F. Mammen Award announcements: Part I-Most popular articles. Semin Thromb Hemost 2017;43(04): 357-363
40 Favaloro EJ. 2017 Eberhard F. Mammen Award announcements: Part II-Young investigator awards. Semin Thromb Hemost 2018; 44(02):81-88

41 Favaloro EJ. 2018 Eberhard F. Mammen Award announcements: Part I-Most popular articles. Semin Thromb Hemost 2018;44(03): 185-192

42 Favaloro EJ. 2018 Eberhard F. Mammen Award announcements: Part II-Young investigator awards. Semin Thromb Hemost 2019; 45(02):123-129

43 Lisman T, de Moerloose P. The role of fibrinogen and factor XIII in hemostasis, and the identification and treatment of associated disorders. Semin Thromb Hemost 2016;42(04):331-332

44 Hvas AM. Platelet function in thrombosis and hemostasis. Semin Thromb Hemost 2016;42(03):183-184

45 Coppola A, Tagliaferri A, Franchini M. Controversies in inherited bleeding disorders. Semin Thromb Hemost 2016;42(05):459-462

46 Kwaan H, Lisman T, Medcalf RL. Fibrinolysis: biochemistry, clinical aspects, and therapeutic potential. Semin Thromb Hemost 2017;43(02):113-114

47 Adcock DM, Gosselin RC. Laboratory assessment of hemostatic and anticoagulant therapy. Semin Thromb Hemost 2017;43(03):242-244 